\title{
Pengaruh Kompetensi Sumber Daya Manusia dan Pemanfaatan Teknologi Informasi terhadap Kualitas Laporan Keuangan
}

\author{
Nabila Zubaidi $^{1 *}$, Dwi Cahyono ${ }^{2}$, Astrid Maharani ${ }^{3}$ \\ 1,2,3Fakultas Ekonomi, Universitas Muhammadiyah Jember, Jawa Timur, Indonesia
}

\author{
A R T I C L E I N F O \\ Article history: \\ Received 19 February 2019 \\ Received in revised form \\ 16 March 2019 \\ Accepted 15 April 2019 \\ Available online 26 May \\ 2019 \\ Kata Kunci: \\ Kompetensi Sumber Daya \\ Manusia, Pemanfaatan \\ Teknologi Informasi, \\ Kualitas Laporan Keuangan \\ Keywords: \\ Competence Of Human \\ Resources, Utilization of \\ Information Technology, \\ Quality Of Financial \\ Statements
}

\begin{abstract}
A B S T R A K
Penelitian ini bertujuan untuk menganalisis pengaruh kompetensi sumber daya manusia dan penggunaan teknologi informasi pada kualitas laporan keuangan (studi kasus di Dinas Pendidikan dan Kebudayaan Situbondo dan Biro Layanan Informasi dan Komunikasi). Sampel dalam penelitian ini adalah karyawan / karyawan \& karyawan pengguna teknologi informasi di tiga bank syariah situbondo, yang berjumlah 99 orang. Metode analisis data yang digunakan dalam penelitian ini adalah metode analisis regresi linier berganda. Uji hipotesis yang digunakan adalah uji $\mathrm{t}$, uji $\mathrm{F}$ dan koefisien determinasi. Hasil penelitian menunjukkan bahwa Kompetensi SDM berpengaruh terhadap Kualitas Laporan Keuangan di Kantor Pendidikan dan Kebudayaan Situbondo dan Biro Layanan Informasi dan Komunikasi. Pemanfaatan Teknologi Informasi mempengaruhi Kualitas Laporan Keuangan di Kantor Pendidikan dan Kebudayaan Situbondo dan Biro Layanan Informasi dan Komunikasi.
\end{abstract}

\section{A B S T R A C T}

This study aims to analyze the influence of competencies in human resources and the use of information technology on the quality of financial statements (case studies at the Education and Culture Office of Situbondo and the Information and Communication Services Bureau). The sample in this study are employees / employees \& employees of information technology users in three situbondo Islamic banks, amounting to 99 people. The data analysis method used in this study is a multiple linear regression analysis method. The hypothesis test used is the t test, $F$ test and coefficient of determination. The results of the study showed that HR Competence had an effect on the Quality of Financial Reports at the Education and Culture Office of Situbondo and the Information and Communication Services Bureau. Utilization of Information Technology affects the Quality of Financial Statements at the Education and Culture Office of Situbondo and the Information and Communication Services Bureau.

\footnotetext{
* Corresponding author.

E-mail addresses: nabilazubaidi1@gmail.com (Nabila Zubaidi)
} 


\section{Pendahuluan}

Laporan keuangan berdasarkan Standar Akuntansi Pemerintahan (SAP) merupakan media yang di gunakan oleh entitas terkhusus pemerintah untuk mempertanggung jawabkan kinerja keuangan kepada pihak yang berkepentingan (publik). Dari perspektif rakyat di daerah, laporan keuangan pemerintah daerah yang disusun sesuai dengan SAP dapat menjelaskan bagaimana pemerintah mengelola keuangan dalam melaksanakan pembangunan sehingga dapat meningkatkan kesejahteraan masyarakat. Standar tersebut dikukuhkan dengan terbitnya Peraturan Pemerintah Nomor 71 Tahun 2010 tentang Standar Akuntansi Pemerintahan. Laporan keuangan yang berkualitas dihasilkan oleh sumber daya manusia (SDM) yang berkompeten dibidang pengelola keuangan. SDM harus memiliki kompetensi dibidang akuntansi dalam pembuatan laporan keuangan yang sesuai dengan Standar Akuntansi Pemerintahan agar laporan keuangan tersebut memiliki kualitas yang baik. Permasalahan umum yang terjadi di pemerintahan khususnya pemerintah daerah bahwa untuk menerapkan manajemen sumber daya manusia, seringkali yang dilakukan tidak sesuai dengan kebutuhan baik secara kuantitas maupun kualitas.

Ada beberapa studi kasus dalam penelitian ini terkait variabel yang di angkat yaitu Kompetensi dan Teknologi Informasi pada dua Dinas Pemerintahan Situbondo tersebut. Alasan peneliti mengambil obyek penelitian pada dua Dinas Pemerintahan Situbondo ini selain kualitas laporan keuangan yang berbeda ini dan juga di dasari atas hasil observasi dan wawancara yaitu dilakukan pada saat pra penelitian, peneliti menemukan suatu fenomena masalah yang cukup menarik untuk diteliti. Dikarenakan tingkat kompetensi SDM mengenai kehadiran karyawan pada dua Dinas Pemerintahan Situbondo di lihat dari data absensi. Fenomena selanjutnya adalah pemanfaatan teknologi informasi, dari hasil survey menunjukan bahwa dua Dinas Pemerintahan yang ada di kabupaten situbondo sudah menggunkan teknlogi informasi.

Munculnya teori berbasis sumber daya (Resources Based Theory) dapat menjelaskan hubungan antara teknologi informasi dengan kinerja perusahaan. Teori ini bermula dari pemahaman terhadap keanekaragaman sumber daya yang dimiliki perusahaan dan lebih memfokuskan pada keunggulan yang didasari firm-specific resources. Penelitian yang dikembangkan oleh Powell dan Dent-Micallef (2007), tentang kerangka teori berbasis sumber daya yang integratif, telah memberikan hasil studi empiris dengan mendukung pendapat bahwa teknologi informasi menciptakan nilai ekonomis dengan berperan sebagai daya ungkit (leverage) dan dengan pemanfaatan sumber daya manusia maupun sumber daya fisik lainnya yang dimiliki oleh perusahaan (Ghozali dan Hapsari, 2006). Berdasarkan teori ketergantungan sumber daya (resource dependence theory) ukuran perusahaan merupakan faktor operasional terpenting yang mempengaruhi perilaku perusahaan dalam merespon lingkungan barunya. Perusahaan besar lebih inovatif dikarenakan kemampuannya untuk menanggung resiko yang lebih besar. Perusahaan besar diharapkan memiliki sumber daya dan infrastuktur untuk melakukan respon terhadap lingkungannya. Dengan demikian semakin meningkatnya skala produksi, teknologi produksi yang digunakan akan semakin cost effective, yang diakibatkan oleh adanya skala ekonomi.

Kompetensi diartikan sebagai kemampuan dasar dan kualitas kerja yang diperlukan untuk mengerjakan pekerjaan dengan baik (Furham, 1990). Menurut Aruan (2003) dalam Fikri et al. (2015) Kompetensi aparatur pemerintah daerah berarti kemampuan yang harus dimiliki seseorang aparatur berupa pengetahuan, ketrampilan, sikap dan prilaku yang diperlukan dalam pelaksanaan tugasnnya. Kompetensi sangat diperlukan dalam menunjang pelaksanaan tugas demi keberhasilan organisasinya. Keberhasilan suatu organisasi dalam mencapai suatu tujuan sangat ditentukan oleh kualitas dan kemampuan Sumber Daya Manusia (SDM) yang berada di dalamnya. Dalam organisasi publik, peran SDM lebih ditekankan pada kemampuan memberikan pelayanan yang terbaik bagi masyarakat, sehingga organisasi tetap memiliki reputasi kinerja yang unggul dan akuntabel dimata masyarakat. Oleh karenanya, kompetensi SDM pada setiap level manajemen menjadi urgen baik level pimpinan maupun staf pemerintahan.

Menurut Bodnar dan Hopwood (2010) sistem informasi akuntansi adalah : sistem informasi akuntansi merupakan kumpulan sumber daya, seperti manusia dan peralatan, yang dirancang untuk mengubah data keuangan dan data lainnya ke dalam informasi. Sedangkan menurut Romney dan Steinbart (2009) sistem informasi akuntansi adalah: sistem informasi akuntansi merupakan sistem yang mengumpulkan, mencatat, menyimpan dan memproses data sehingga menghasilkan informasi untuk pengambilan keputusan.

Perkembangan teknologi informasi tidak hanya digunakan dalam organisasi sektor swasta tetapi juga dalam organisasi sektor publik, termasuk pemerintah. Dalam penjelasan Peraturan Pemerintah Nomor 56 Tahun 2005 tentang Sistem Informasi Keuangan, disebutkan bahwa untuk menindaklanjuti pelaksanaan proses pembangunan sejalan dengan prinsip-prinsip tata kelola yang baik, Pemerintah Pusat dan Daerah yang berkewajiban untuk mengembangkan dan memanfaatkan kemajuan teknologi informasi 
untuk meningkatkan kemampuan untuk mengelola keuangan, dan mendistribusikan informasi keuangan kepada pelayanan publik.

Menurut Hopwood (2004), Laporan keuangan adalah suatu alat pertanggung jawaban atas kinerja keuangan manajemen suatu pemerintahan kepada publik yang dipercayakan kepadanya. Laporan keuangan merupakan hasil akhir dari proses kegiatan akuntansi atau suatu ringkasan dari transaksi keuangan. Laporan keuangan pada organisasi pemerintahan merupakan asersi dari pihak manajemen pemerintah yang menginformasikan kepada pihak lain (stakeholder) tentang kondisi keuangan pemerintah.

Menurut Spencer (1993), Syarifuddin (2014), kompetensi adalah suatu karakteristik yang mendasari kepribadian seseorang yang menyebabkan saling berkaitan dengan kriteria-keperilakuan efektif atau kinerja yang unggul dalam pekerjaan atau situasi tertentu. Laporan keuangan merupakan produk yang dihasilkan oleh sumber daya manusia dibidang akuntansi. Jadi untuk dapat menghasilkan laporan keuangan yang berkualitas maka dibutuhkan sumber daya manusia yang berkompeten dalam membuat laporan keuangan. Hasil penelitian yang mendukung pengaruh kompetensi sdm terhadap kualitas laporan keuangan yaitu dilakukan oleh Wati dan Pratiwi. Spencer (1993) menunjukkan kompetensi sumber daya manusia berpengaruh positif dan signifikan terhadap kualitas laporan keuangan daerah. Sama halnya penelitian Hardiansyah (2016) menunjukkan bahwa sumber daya manusia berpengaruh terhadap nilai informasi keuangan. Temuan ini juga didukung oleh peneliti sebelumnya yang dilakukan oleh Hardiansyah (2016), Safiyulloah (2017), Andrianto (2017) yang menerangkan bahwa Kompetensi SDM berpengaruh terhadap laporan keuangan.

Dalam dunia modern saat ini, penggunaan teknologi informasi menjadi suatu keharusan. Teknologi informasi dapat membantu sumber daya manusia dalam mengelola keuangan. Meskipun laporan keuangan adalah produk yang dihasilkan oleh sumber daya manusia dibidang akuntansi tapi memanfaatkan teknologi bias meminimalisir kesalahan dari manusia itu sendiri. Menurut Hamzah (2009), pemanfaatan teknologi informasi tersebut mencakup adanya (a) pengolahan data, pengolahan informasi, system manajemen, dan proses kerja secara elektronik, dan (b) pemanfaatan kemajuan teknologi informasi agar pelayanan publik dapat diakses secara mudah dan murah oleh masyarakat di seluruh wilayah negeri ini.

Pengolahan data menjadi suatu informasi dengan bantuan komputer jelas akan lebih meningkatkan nilai dari informasi yang dihasilkan (Hanafi, 2013). Maka dengan mengoptimalkan pemanfaatan teknologi informasi akan lebih meningkatkan kualitas laporan keuangan. Maka dari pemerintah daerah diharuskan untuk memanfaatkan kemajuan teknologi yang berguna untuk meningkatkan kemampuan dalam mengelola keuangan daerah sesuai dengan peraturan pemerintah No.56 tentang Sistem Informasi Keuangan Daerah. Hasil penelitian sebelumnya yang dilakukan oleh Hardiansyah (2016), Safiyulloah (2017), Andrianto (2017). Penelitian mereka menunjukkan bahwa pemanfaatan teknologi informasi berpengaruh signifikan terhadap kualitas laporan keuangan pemerintah daerah.

\section{Metode}

Jenis data yang digunakan pada penelitian ini adalah data subyek. Sumber data pada penelitian ini adalah data primer. Variabel dependen dalam penelitian ini adalah Kualitas informasi laporan keuangan. Laporan Keuangan suatu alat pertanggungjawaban atas kinerja keuangan manajemen suatu pemerintahan kepada publik yang dipercayakan kepadanya. Kualitas informasi laporan keuangan adalah ukuran-ukuran normatif yang perlu diwujudkan pada informasi yang disajikan dalam laporan keuangan. Pengukuran dengan menggunakan karakteristik kualitatif laporan keuangan (Herman, 2015) yaitu relevan (indikator: memiliki umpan balik (feedback value), manfaat prediktif, tepat waktu, lengkap.

Variabel independen dalam penelitian ini yakni Kompetensi SDM dan Pemanfaatan Teknologi Informasi:

a. Kompetensi SDM (X1)

Kompetensi Sumber Daya Manusia adalah kemampuan pegawai atau suatu sistem untuk melaksanakan fungsi-fungsi atau kewenangannya untuk mencapai tujuan secara efektif dan efisien. Kompetensi harus dilihat sebagai kemampuan untuk mencapai kinerja, untuk menghasilkan keluarankeluaran (output) dan hasil-hasil (outcomes) (Ihsanti, 2014) Indikator pengukurannya adalah Kemampuan, Keterampilan, Pemahaman dan pengetahuan (Havesi,2005).

b. Pemanfaatan Teknologi Informasi (X2)

Pemanfaatan teknologi informasi adalah penggunaan teknologi baik itu perangkat lunak dan keras yang diharapkan akan memberikan manfaat bagi pegawai dalam menjalani tugas dan fungsinya. Indikator pengukurannya adalah jumlah Komputer yang memadai, pemanfaatan jaringan internet, proses akuntansi dilakukan secara komputerisasi, penggunaan software sesuai dengan undang-undang (Zuliarti, 2012) 
Metode analisis data yang digunakan dalam penelitian ini adalah metode analisis statistik dengan persamaan regresi linier berganda dengan menggunakan aplikasi SPSS.

\section{Hasil dan pembahasan}

Gambaran Umum Objek Penelitian

Satuan Kerja Perangkat Daerah atau SKPD adalah pelaksana fungsi eksekutif yang haru berkoordinasi agar penyelenggaraan pemerintahan berjalan dengan baik. SKPD adalah instansi pemerintah daerah yang bertanggung jawab atas bidang tugas yang dipikul oleh suatu Badan Layanan Umum (BLU). SKPD bertanggung jawab dalam rangka penyelenggaraan pemerintahan yang terdiri atas sekretaris daerah, dinas daerah dan lembaga teknis daerah, kecamatan, polisi dan pamong praja sesuai kebutuhan daerahnya.

Deskriptif Karakteristik Responden

Berikut ini disajikan statistik deskriptif untuk masing-masing variabel yang digunakan dalam penelitian ini dan data tentang karakteristik responden. Berikut ini disajikan statistik deskriptif untuk masing-masing variabel yang digunakan dalam penelitian ini dan data tentang karakteristik responden. Data yang digunakan dalam penelitian ini meliputi data-data sebagai berikut: Umur, Jenis Kelamin dan Pendikikan Terkahir. Data deskriptif responden sebagai berikut:

1. Karakteristik Responden Berdasarkan Umur

Tabel 1. Umur Responden

\begin{tabular}{ccc}
\hline Umur & Jumlah & Persentase (\%) \\
\hline $21-25$ tahun & 13 & 13,1 \\
$26-30$ tahun & 24 & 24,2 \\
$31-35$ tahun & 37 & 37,5 \\
$36-40$ tahun & 14 & 14,1 \\
$>40$ tahun & 11 & 11,1 \\
\hline Jumlah & 99 & $100 \%$ \\
\hline
\end{tabular}

Sumber : data primer diolah, 2018

Tabel 1 menunjukkan bahwa jumlah responden yang berumur 21 - 25 tahun sebanyak 13 orang $(13,1 \%), 26$ - 30 tahun sebanyak 24 orang $(24,2 \%), 31-35$ tahun sebanyak 37 orang $(37,5 \%), 36-40$ tahun sebanyak 14 orang $(14,1 \%)$ dan $>40$ tahun sebanyak 11 orang $(11,1 \%)$.

Tabel 2. Jenis Kelamin Responden

\begin{tabular}{ccc}
\hline Jenis Kelamin & Jumlah & Persentase (\%) \\
\hline Laki-Laki & 62 & 62,6 \\
Perempuan & 37 & 37,4 \\
\hline Total & 99 & 100 \\
\hline & & Sumber : data primer diolah, 2018
\end{tabular}

Tabel 2 menunjukkan bahwa jumlah responden yang berjenis kelamin laki-laki yaitu sebanyak 62 orang $(62,6 \%)$, sedangkan yang berjenis kelamin perempuan yaitu sebanyak 37 orang $(37,4 \%)$.

2. Karakteristik Responden Berdasarkan Pendidikan Terakhir

Tabel 3. Pendidikan Responden

\begin{tabular}{ccc}
\hline Jenis Kelamin & Jumlah & Persentase (\%) \\
\hline SMA & 7 & 7,1 \\
DIPLOMA & 12 & 12,1 \\
S1 & 71 & 71,7 \\
S2 & 9 & 9,1 \\
\hline
\end{tabular}


Tabel 3 menunjukkan bahwa jumlah responden yang berpendidikan terakhir SMA yaitu sebanyak 7 orang $(7,1 \%)$, responden yang berpendidikan terakhir DIPLOMA yaitu sebanyak 12 orang (12,1\%), responden yang berpendidikan terakhir S1 yaitu sebanyak 71 orang $(71,7 \%)$ dan responden yang berpendidikan terakhir S2 yaitu sebanyak 9 orang $(9,1 \%)$.

\section{Deskripsi Variabel Penelitian}

Deskripsi variabel dalam penelitian ini menjelaskan distribusi frekuensi jawaban responden tentang indikator-indikator yang terdapat dalam pernyataan kuisioner penelitian ini, yaitu Kompetensi SDM $\left(\mathrm{X}_{1}\right)$, Pemanfaatan Teknologi Informasi $\left(\mathrm{X}_{2}\right)$ dan Kualitas Laporan Keuangan (Y). Skor yang diberikan responden pada masing-masing pernyataan yang ada di dalam kuisioner mencerminkan bagaimana persepsi mereka terhadap variabel penelitian. Dari data distribusi frekuensi responden dapat dilihat seberapa besar nilai suatu variabel jika dibandingkan nilai variabel lain, serta bagaimana pola hubungan antar variabel yang ada dalam penelitian.

Deskripsi Variabel Kompetensi SDM $\left(\mathrm{X}_{1}\right)$

Penilain responden terhadap variabel Kompetensi SDM $\left(\mathrm{X}_{1}\right)$, menurut klarifikasi tingkatan skor dari masing-masing pernyataan Kompetensi SDM dijelaskan pada tabel berikut ini:

Tabel 4. Distribusi Frekuensi Jawaban Responden Terhadap Kompetensi SDM

\begin{tabular}{|c|c|c|c|c|c|c|c|c|c|c|c|}
\hline \multirow{2}{*}{$\begin{array}{c}\text { Nomor } \\
\text { Pernyataan }\end{array}$} & \multicolumn{11}{|c|}{ Jawaban Responden } \\
\hline & 5 & $\%$ & 4 & $\%$ & 3 & $\%$ & 2 & $\%$ & 1 & $\%$ & Total \\
\hline $\mathrm{X} 1.1$ & 22 & 22.2 & 58 & 58.6 & 13 & 13.1 & 6 & 6.1 & - & - & 99 \\
\hline $\mathrm{X} 1.2$ & 30 & 30.3 & 47 & 47.5 & 15 & 15.2 & 7 & 7.1 & - & - & 99 \\
\hline $\mathrm{X} 1.3$ & 22 & 22.2 & 63 & 63.6 & 10 & 10.1 & 4 & 4.0 & - & - & 99 \\
\hline $\mathrm{X} 1.4$ & 16 & 16.2 & 54 & 54.5 & 26 & 26.3 & 3 & 3.0 & - & - & 99 \\
\hline Rata-Rata & 22.5 & 22.7 & 55.5 & 56.1 & 16 & 16.1 & 5 & 5.1 & - & - & 99 \\
\hline
\end{tabular}

Berdasarkan data Tabel 4 di atas, dapat diketahui bahwa penilaian terbanyak responden terhadap variabel Kompetensi SDM setuju, yaitu dengan presentasi jawaban pada indikator Kemampuan sebesar 58,6\%, indikator Keterampilan sebesar 47,5\%, indikator Pemahaman sebesar 63,6\% dan indikator pengetahuan sebesar 54,5\%. dari presentase masing-masing indikator diperoleh rata-rata sebesar 56,1\% pada penilaian kriteria jawaban setuju bahwa Kompetensi SDM Dinas Pendidikan dan Kebudayaan Situbondo dan Dinas Komunikasi Informatika dan Persandian Situbondo baik dan sesuai.

4.3.2. Deskripsi Variabel Pemanfaatan Teknologi Informasi $\left(\mathrm{X}_{2}\right)$

Penilain responden terhadap variabel Pemanfaatan Teknologi Informasi $\left(\mathrm{X}_{2}\right)$, dijelaskan pada Tabel 5 berikut ini:

Tabel 5. Distribusi Frekuensi Jawaban Responden Terhadap Pemanfaatan Teknologi Informasi

\begin{tabular}{|c|c|c|c|c|c|c|c|c|c|c|c|}
\hline \multirow{2}{*}{$\begin{array}{c}\text { Nomor } \\
\text { Pernyataan }\end{array}$} & \multicolumn{11}{|c|}{ Jawaban Responden } \\
\hline & 5 & $\%$ & 4 & $\%$ & 3 & $\%$ & 2 & $\%$ & 1 & $\%$ & Total \\
\hline 1 & 31 & 31.3 & 46 & 46.5 & 18 & 18.2 & 4 & 4.0 & - & - & 99 \\
\hline 2 & 19 & 19.2 & 49 & 49.5 & 24 & 24.2 & 7 & 7.1 & - & - & 99 \\
\hline 3 & 12 & 12.1 & 62 & 62.6 & 21 & 21.2 & 4 & 4.0 & - & - & 99 \\
\hline 4 & 9 & 9.1 & 65 & 65.7 & 17 & 17.2 & 8 & 8.1 & - & - & 99 \\
\hline Rata-Rata & 17.7 & 17.9 & 55.5 & 56.1 & 20 & 20.2 & 5.7 & 5.8 & - & - & 99 \\
\hline
\end{tabular}

Sumber : data primer diolah, 2018

Berdasarkan data Tabel 5 di atas, dapat diketahui bahwa penilaian terbanyak responden terhadap variabel Pemanfaatan Teknologi Informasi setuju, yaitu dengan presentasi jawaban pada indikator jumlah Komputer yang memadai sebesar 46,5\%, indikator pemanfaatan jaringan internet 
sebesar 49,5\%, indikator proses akuntansi dilakukan secara komputerisasi sebesar $62,6 \%$ dan indikator nggunaan software sesuai dengan undang-undang sebesar 65,7\%. dari presentase masing-masing indikator diperoleh rata-rata sebesar $56,1 \%$ pada penilaian kriteria jawaban setuju bahwa Pemanfaatan Teknologi Informasi pada Dinas Pendidikan dan Kebudayaan Situbondo dan Dinas Komunikasi Informatika dan Persandian Situbondo baik dan sesuai.

Deskripsi Variabel Kualitas Laporan Keuangan (Y)

Penilain responden terhadap variabel Kualitas Laporan Keuangan (Y), menurut klarifikasi tingkatan skor dari masing-masing pernyataan Kualitas Laporan Keuangan dijelaskan pada tabel berikut ini:

Tabel 6. Distribusi Frekuensi Jawaban Responden Terhadap Kualitas Laporan Keuangan

\begin{tabular}{|c|c|c|c|c|c|c|c|c|c|c|c|}
\hline \multirow{2}{*}{$\begin{array}{c}\text { Nomor } \\
\text { Pernyataan }\end{array}$} & \multicolumn{11}{|c|}{ Jawaban Responden } \\
\hline & 5 & $\%$ & 4 & $\%$ & 3 & $\%$ & 2 & $\%$ & 1 & $\%$ & Total \\
\hline 1 & 12 & 12.1 & 66 & 66.7 & 14 & 14.1 & 7 & 7.1 & - & - & 99 \\
\hline 2 & 25 & 25.3 & 58 & 58.6 & 13 & 13.1 & 3 & 3.0 & - & - & 99 \\
\hline 3 & 11 & 11.1 & 69 & 69.7 & 10 & 10.1 & 9 & 9.1 & - & - & 99 \\
\hline 4 & 18 & 18.2 & 67 & 67.7 & 10 & 10.1 & 4 & 4.0 & - & - & 99 \\
\hline Rata-Rata & 16.5 & 16.6 & 65 & 65.6 & 11.7 & 11.8 & 5.7 & 5.8 & - & - & 99 \\
\hline
\end{tabular}

Sumber : data primer diolah, 2018

Berdasarkan data Tabel 6 di atas, dapat diketahui bahwa penilaian terbanyak responden terhadap variabel Kualitas Laporan Keuangan setuju, yaitu dengan presentasi jawaban pada indikator memiliki umpan balik sebesar $66,7 \%$, indikator manfaat prediktif sebesar 58,6\%, indikator tepat waktu sebesar $69,7 \%$ dan indikator lengkap sebesar $67,7 \%$. dari presentase masing-masing indikator diperoleh rata-rata sebesar 65,6\% pada penilaian kriteria jawaban setuju bahwa Kualitas Laporan Keuangan Dinas Pendidikan dan Kebudayaan Situbondo dan Dinas Komunikasi Informatika dan Persandian Situbondo baik dan sesuai.

Adapun hasil Hipotesis dapat diringkas seperti pada table sebagai berikut: Uji t adalah suatu uji untuk pengaruh secara parsial variabel bebas terhadap variabel terikat. Hasil uji t sebagai berikut: Uji statistik t disebut juga sebagai uji signifikansi individual. Uji ini menunjukan seberapa jauh pengaruh variabel independen secara parsial terhadap variabel dependen. Hasil uji t sebagai berikut:

Tabel 7. Hasil Uji t

\begin{tabular}{lccc}
\hline \multicolumn{1}{c}{ Variabel } & t tabel & t hitung & Sig \\
\hline Kompetensi SDM $\left(\mathrm{X}_{1}\right)$ & 1,664 & 6,572 & 0,000 \\
Pemanfaatan Teknologi Informasi $\left(\mathrm{X}_{2}\right)$ & 1,664 & 4,609 & 0,000 \\
\hline
\end{tabular}

Sumber: data primer diolah, 2018

Berdasarkan Tabel 7 tersebut dapat diketahui besar dari pengaruh masing-masing variabel independen terhadap variabel dependen sebagai berikut :

1. Kompetensi SDM $\left(\mathrm{X}_{1}\right)$ terhadap variabel Kualitas Laporan Keuangan $(\mathrm{Y})$

Berdasarkan Tabel 4.7 dapat dilihat bahwa Tingkat signifikansi $(\alpha)$ dari variabel Kompetensi SDM $\left(\mathrm{X}_{1}\right)$ adalah 0,000 $<0,05$ dan nilai t hitung 6,572 $>\mathrm{t}$ table 1,664. Hal ini berarti Partisipasi Pemakai Sistem Informasi berpengaruh signifikan terhadap Kualitas Laporan Keuangan $\left(\mathrm{H}_{1}\right.$ diterima).

2. Pemanfaatan Teknologi Informasi $\left(\mathrm{X}_{2}\right)$ terhadap variabel Kualitas Laporan Keuangan $(\mathrm{Y})$

Berdasarkan Tabel 4.7 dapat dilihat bahwa Tingkat signifikansi $(\alpha)$ dari variabel Pemanfaatan Teknologi Informasi $\left(\mathrm{X}_{2}\right)$ adalah $0,000<0,05$ dan nilai t hitung 4,609 $>\mathrm{t}$ table 1,664. Hal ini berarti Partisipasi Pemakai Sistem Informasi berpengaruh signifikan terhadap Kualitas Laporan Keuangan $\left(\mathrm{H}_{2}\right.$ diterima).

\section{Simpulan dan saran}

Berdasarkan hasil analisis dan pembahasan yang telah peneliti jelaskan maka dapat disimpulkan sebagai berikut hasil pengujian regresi berganda atas pengaruh Kompetensi SDM terhadap Kualitas Laporan Keuangan menunjukkan hubungan yang positif signifikan. Ini membuktikan bahwa Kompetensi 
SDM yang baik akan meningkatkan Kualitas Laporan Keuangan. Hasil pengujian regresi berganda atas pengaruh Pemanfaatan Teknologi Informasi terhadap Kualitas Laporan Keuangan menunjukkan hubungan yang positif signifikan. Ini membuktikan bahwa Pemanfaatan Teknologi Informasi yang baik akan meningkatkan Kualitas Laporan Keuangan.

Dari kesimpulan di atas penulis memberikan saran kepada Dinas Pendidikan dan Kebudayaan Situbondo dan Dinas Komunikasi Informatika dan Persandian Situbondo untuk mengatasi permasalahan yang dihadapi Seharusnya dalam pergantian posisi sebagai pimpinan, kasubag, maupun staf terlebih bagian penyususnan laporan keuangan tidak di mutasi terlebih dahulu agar laporan keuangan yang terjadi tidak di tertunda dan tidak terjadi pengendapan dana.

\section{Daftar Rujukan}

Anik Irawati, Lilis Endang Wijayanti. 2005. Pengaruh Partisipasi Pemakai dan Kepuasan Pemakai Terhadap Kinerja Sistem Informasi. JMK.

Ambar Teguh Sulistiyani dan Rosidah, 2008, Manajemen Sumber Daya Manusia, Graha Ilmu : Yogyakarta

Amrul, Sadat dan Syar'ie, Ahyadi, 2005, Analisis Beberapa Faktor Yang Berpengaruh Terhadap Proses Pengembangan Kualitas Sistem, Solo: Simposium Nasional Akuntansi VIII

Anik Irawati, Lilis Endang Wijayanti, 2005, Pengaruh Partisipasi Pemakaidan Kepuasan Pemakai Terhadap Kinerja Sistem Informasi, Skripsi, Fakultas Ekonomi, Universitas Muhamadiyah Malang

Azhar Susanto, 2008, Sistem Informasi Akuntansi, Struktur - Pengendalian - Resiko - Pengembangan, ed, Perdana, Cetakan Pertama, Lingga Jaya, Bandung

Bambang Wahyudi, 2006, Manajemen Sumber Daya Manusia. Penerbit Sulita Bandung

Bodnar, George H, \& Hopwood, William S, 2010, Accounting Information System, Tenth Edition, Pearson Education inc, Upper saddle River, New Jersey

Bonner, S. E. \& Sprinkle. 2002. A Model of The Effects of Audit Task Complexity, Accounting, Organizations and Society., 19 (3): 213-234.

Campbell, N. A, 2000, International Student Edition Biology, Singapore : Addison Wesley Longman, Inc

Choe, Jong-Min, 1996, The Relationship Among Performance of Accounting Information System, Influence factor, and Evolution Level of Information System, Journal Management Information System, Vol 12 iss,

Fung Jen.2008. “Faktor-Faktor Yang Mempengaruhi Kinerja Sistem Informasi Akuntansi,"Jurnal Bisnis dan Akuntansi Volume IV No.2

Goodhue, D.I 1995. “Task -Technology and Individual Performance”. Mis Quarterly, Juni 213-236.

Ghozali, Hapsari, 2006, Pengaruh Teknologi Informasi Berbasis Sumber Daya Terhadap Kinerja Perusahaan, Jurnal Maksi, Vol,6 No,1 (60-68).

Ghozali, Imam. 2013. Aplikasi Analisis Multivariate dengan Program IBM SPSS 19. Semarang: UNDIP.

Ginzberg, M.J. April 1981. "Early Diagnosis of Implementation Failure: Priopmising Result and Unanswered Question". Management Sciences. Vol. 27, No. 4

Gomes, Faustino Cardoso, 2009, Manajemen Sumber Daya Manusia, Edisi kelima,Yogyakarta

Hasibuan, Malayu, 2006, Manajemen Sumber Daya Manusia, Jakarta: BumiAksara

, Manajemen Sumber Daya Manusia, Edisi kedua, Jakarta: BumiAksara 
Hunton \& Kenneth (1994). Management Information Systems: Managing the Digital Firm, 10th edition. Pearson Education, Inc., New Jersey

Jiambalvo, J. dan Pratt, J. 1982. Task Complexity and Leadership Effectiveness in CPA Firms. The Accounting Review, Vol LVII, No.4.

Jogiyanto , 2008, Sistem Informasi Keperilakuan, CV Andi Offset, Yogyakarta 2007. Model Kesuksesan Sistem Teknologi Informasi, CV Andi Offset, Yogyakarta

Komar, 2005, Analisis Faktor Faktor Yang Mempengaruhi Kinerja Sistem Informasi Akuntansi, SNAVIII, Solo

Lau Elfreda Aplonia, 2005, Pengaruh partisipasi Pemakai Terhadap Kepuasan pemakai dalam Pengembangan Sistem Informasi dengan Lima Variabel Moderating, Jurnal riset Akuntansi Indonesia

Lawrence, M dan Choe. 1996. “Exploring Individual User Satisfaction Within User Led Development.” MIS Quartely. June.

Luciana Spica Almalia \& Irmaya Briliantine, 2007, Analisis Faktor Faktor Yang Mempengaruhi Kinerja Sistem Informasi Akuntansi Pada Bank Umum Pemerintah di wilayah Surabya dan Sidoarjo, STIE Perbanas Surabaya

McLeod Jr, Raymond, George P, Schell, 2007, Sistem Informasi Manajemen, PT, Indeks, Jakarta

McKeen dkk. (1994). Biochemistry: The Moleculer Basis of Life. New York: McGraww-Hill.

Mohd-Sanusi, Z. and Iskandar, T.M. 2007. Audit Judgment Performance: Assessing the Effect of Performance Incentives, Effort and Task Complexity. Managerial Auditing Journal, 22: 34-52.

Muntoro R.K. 1994. "The Use of Organization Behavior Methods in The Development of Computerized Accounting System in Indonesia: An Attidudial Survey." Ph.D. Dissertation. Accountancy Development in Indonesia Publication.

Nugroho, Eko, 2008, Peran Sistem Informasi Dalam Menciptakan Keunggulan Daya Saing, KELOLA No, 6/III Mei 2008

Numaker \& Ralph, Akuntansi Pemerintahan, edisi 4, Jakarta: Erlangga, 1996.

Nura Ruslia, 2011, Analisis Faktor-Faktor Yang Berpengaruh Terhadap Kinerja Sistem Informasi Akuntansi, Skripsi, Universitas Pasundan

Pratiwi Elsa. 2010. Pengaruh Profitabilitas, Financial Leverage, dan Pertumbuhan Perusahaan terhadap Tindakan Perataan Laba. Jurnal Akuntansi 1(3): 1-23.

Pratomo et.al. 2009. Reksa Dana Solusi Perencanaan Investasi di Era Modern. PT. Garamedia Pustaka Utama. Jakarta

Reichheld, F.F \& Izak. (1996), The Loyalty Effect, Harvard Business School Press, Boston, MA.

Robbins, Stephen P,, 2005, Organizational Behavior, Elevent Edition, International Edition, Pearson Education inc,, San Diego State University, Upper Saddle river, New jersey

Romney, Marshall B, \& pal Jhon Steinbart, 2009, Accounting Information System, Eleventh Edition, Prentice Hall 
Sadatamrul, 2004, Hubungan Antara Partisipasi Dalam Pemgembangan Sistem Informasi Dengan Perkembangan Penggunaan Teknologi Informasi (Suatu Tinjauan Dengan Dua Faktor Kontijensi), Seminar Nasional Akuntansi VII, 2-3 Desember

Salam, Darma Setyawan, 2007, Manajemen Pemerintahan Indonesia,Jakarta : Djambatan

Sedarmayanti, 2009, Sumber Daya Manusia dan Produktivitas Kerja, Bandung: CV, Mandar Maju

Sekaran, Uma. 2006. Research Methods For Business (Metodologi Penelitian untuk Bisnis). Jakarta: Salemba Empat.

Setianingsih, I. 2008. "Sistem Pengendalian Internal atas Aktiva tetap pada Fakultas Ekonomi Univesitas Sumtra Utara”. Diploma III Fakultas Ekonomi Universitas Sumatra Utara.

Manajemen Sumber Daya Manusia Reformasi Birokrasi dan Manajemen Pegawai Negeri Sipil, Bandung: Rafika ADITAMA

Sofyandi, Herman, 2008, Manajemen Sumber Daya Manusia, Penerbit: Graha Ilmu, Yogyakarta

Sugiarto Prajitno, 2006, Analisis faktor-faktor Yang Berpengaruh Terhadap Kinerja SIA Dengan Kompleksitas Tugas sebagai Variabel Moderating, Jurnal Akuntansi

Sugiyono, 2008, Metode penelitian Bisnis, ed, Revisi, Cetakan Delapan Belas, CV, Alafabetha, Bandung

Supomo dan Nur Indriantoro, 2009, Pengaruh Partisipasi Terhadap Kepuasan Pemakai Dalam Pengembangan Sistem Informasi Dengan Kompleksitas Tugas, Kompleksitas Sistem dan Pengaruh Pemakai Sebagai Moderating Variable, Jurnal Analisis Bisnis dan Ekonomi, Vol,2,No, 2 : hal 105-123

Sutrisno, Edy, 2009, Manajemen Sumber Daya Manusia, Edisi Pertama, Cetakan Pertama, Penerbit Kencana, Jakarta

Szajna dan Scammell, 1993. "The Effect of Information System User Expectation on Their Performance and Perception". MIS Quartely

Terry, George R, dan Rue, Leslie W, 2005, Dasar-Dasar Manajemen, Jakarta : Bumi Aksara

Veithzal, 2004, Manajemen Sumber Daya Manusia Untuk Perusahaan dari Teori KePraktik. Jakarta : PT. Raja Grafindo Persada.

Wibowo. 2007. Sistem Akuntansi dan Informasi. Terjemahan Marianus Sinaga. Erlangga, Jakarta.

Wijaya. (2004). Kamus Lengkap Inggris-Indonesia. Semarang: Bintang Jaya.

Wilkinson, Joseph, W, 2010, Accounting Information System, Fourth Edition, United States, New York, Jhon Wilwy and Sons Inc

Wood, R. E. 1986. Task Complexity. Definition of The Construct. Organizational Behaviour and Human Decision Process, pp.60-82.

Wulandari. 2006. Karakteristik Good Corporate Governance. Alfabeta. Bandung. 